\title{
Comparative effects of extracted polyphenols from black and green tea wastes on in-vitro fermentability of feed ingredients
}

\section{Efeitos comparativos dos polifenóis extraídos dos resíduos do chá preto e verde na fermentabilidade in vitro dos ingredientes da ração}

\author{
Nazak Shokrani Gheshlagh"; Hamid Paya2*; Akbar Taghizadeh; \\ Hamid Mohammadzadeh2; Valiollah Palangi4; Yousef Mehmannavaz ${ }^{5}$
}

\section{Highlights}

In this study, using the black and green tea wastes extract without reducing the digestibility, the digestion site of nutrients was transferred from the rumen to the intestine.

\begin{abstract}
The effect of using black and green tea waste extracts on the diet nutritional value was investigated with three methods of in vitro degradability, gas production, and McNiven's enzymatic digestion in the present experiment. Total phenolic compounds and total tannin for green tea extract were $20.3 \%$ and $14.8 \%$ of dry matter (DM), respectively, and for black tea were $18.7 \%$ and $12.7 \%$ of dry matter, respectively. The addition of green and black tea waste extracts reduced both gas production during incubation hours and dry matter degradability (DMD) in the diet $(p<0.05)$. A significantly reduced ruminal dry matter disappearance $(p<0.05)$ and a significantly increased post-ruminal dry matter disappearance $(p<0.05)$ were observed by adding black and green tea waste extracts. According to the results, the dry matter disappearance throughout the gastrointestinal tract was not significantly different between treatments. It can generally be concluded that the addition of phenolic compounds can be used depending on the nutritional strategy, such as reducing ruminal degradability and increasing rumen nutrient escape.
\end{abstract}

Key words: Black and green tea waste. Gastrointestinal tract. In vitro. Nutritional value.

1 Student, Department of Animal Science, Faculty of Agriculture, University of Tabriz, Tabriz, Iran. E-mail: nazakshokrani373@gmail.com

2 Assistant Profs., Department of Animal Science, Faculty of Agriculture, University of Tabriz, Tabriz, Iran. E-mail: hamid.paya@tabrizu.ac.ir; hamidmhz@tabrizu.ac.ir

${ }^{3}$ Full Prof., Department of Animal Science, Faculty of Agriculture, University of Tabriz, Tabriz, Iran. E-mail:a_tagizadeh@ tabrizu.ac.ir

${ }^{4}$ Researcher, Department of Animal Science, Agricultural Faculty, Ataturk University, 25240, Erzurum, Turkey. E-mail: valiollah.palangi12@ogr.atauni.edu.tr

${ }^{5}$ Associate Prof., Department of Animal Science, Maragheh Branch, Islamic Azad University, Maragheh, Iran. E-mail: mehman10@iau-maragheh.ac.ir

* Author for correspondence

Received: Mar. 01, 2021 - Approved: Mar. 25, 2021 


\section{Resumo}

O efeito do uso de extratos de resíduos de chá preto e verde sobre o valor nutricional da dieta foi investigado com três métodos de degradabilidade in vitro, produção de gás e digestão enzimática de McNiven no presente experimento. Os compostos fenólicos totais e o tanino total para o extrato de chá verde foram 20,3\% e 14,8\% da matéria seca, respectivamente, e para o chá preto foram 18,7\% e 12,7\% da matéria seca, respectivamente. A adição de extratos de resíduos de chá verde e preto reduziu a produção de gases durante as horas de incubação e a degradabilidade da matéria seca da dieta $(p<0,05)$. Um desaparecimento de matéria seca ruminal significativamente reduzido $(p<0,05)$ e um desaparecimento de matéria seca pósruminal significativamente aumentado $(p<0,05)$ foram observados pela adição de extratos de resíduos de chá preto e verde. De acordo com os resultados, o desaparecimento da matéria seca ao longo do trato gastrointestinal não foi significativamente diferente entre os tratamentos. Em geral, pode-se concluir que a adição de compostos fenólicos pode ser utilizada dependendo da estratégia nutricional, como redução da degradabilidade ruminal e aumento do escape ruminal de nutrientes..

Palavras-chave: Resíduos de chá preto e verde. In vitro. Trato gastrointestinal. Valor nutricional.

\section{Introduction}

Due to the legal prohibition on the use of antibiotics as an additive has increased the tendency to use natural compounds derived from aromatic plants in food and animal nutrition (Besharati, Palangi, Moaddab, Nemati, Pliego, \& Salem, 2020; Cimrin, Tunca, Avsaroglu, Ayasan, \& Küçükersan, 2020). The use of plant secondary compounds, such as tannins derived from tree leaves and legume fodder, is important in ruminant nutrition. There are very extensive studies with often contradictory results concerning the performance of ruminants by the use of tannins due to their concentrations and chemical structure (Piluzza, Sulas, \& Bullitta, 2014). Tannins are high-molecular weight water-soluble polyphenolic compounds that have a high effect on ruminal fermentation, such as decreasing ruminal protein breakdown, decreasing methane production, prevention of bloating, and increasing the conjugated linoleic acid concentration in feeds derived from phenolic compounds in ruminant nutrition (Koenig \& Beauchemin, 2018; Smeriglio, Barreca, Bellocco, \& Trombetta, 2017). In addition, tannins can increase body weight and wool growth and improve milk production efficiency and reproductive performance (Sallam et al., 2019). The effects of tannins on ruminal protozoa, bacteria, fungi and methanogens vary depending on the type, origin, and supplement levels of tannins (Patra \& Saxena, 2011). In many studies, however, the use of tannins as a dietary component is associated with a negative effect on the diet digestibility. Based on studies conducted on live animals, cows fed fodder rich in condensed tannins were suggested to use tannin extracts instead of feeding tannin-rich fodder to improve the ruminal fermentation (Kelln, Penner, Acharya, McAllister, \& Lardner, 2020; Mohamaden, Hegab, \& Shang-li, 2020). The use of waste as a source of nutrients and bioactive compounds has also long been proposed for feeding ruminants, which is an agricultural system to reduce waste and feed cost efficiency and to provide a healthy environment (Salami et al., 2019; Georganas et 
al., 2020). In this regard, the use of tea waste is economically useful and the tannin content should be considered to use this waste (Kondo et al., 2014). Increasing the concentration of condensed tannins in the ruminant diet increases the protein passage rate through the rumen, which is probably due to the reduced degradation ratebyrumenmicroorganismsand decreased growth rate of proteolytic bacterial species (Patra \& Aschenbach, 2018; Min et al., 2020). However, condensed tannins in the ruminant diet also reduce nutrient digestion (Derix, 2017; Samal, Chaudhary, Agarwal, \& Kamra, 2018) and impair fermentation (Adejoro, Hassen, \& Akanmu, 2019). On the other hand, proper intake of tannin-containing compounds has been reported to improve livestock performance (Zhang et al., 2019; Costa et al., 2021). Therefore, it is important to determine the appropriate consumption level of this phenolic compound with no adverse effect on the digestibility. Shakeri, Riasi and Madahian. (2018) investigated the effect of pistachio by-product extract with two solvents (water and methanol) on the dry matter degradability (DMD) and feed crude protein (CP). They reported that the extract extracted by both solvents reduced the ruminal DMD whereas no decrease was observed in the disappearance of the whole gastrointestinal tract (GI). Considering what mentioned above, the high volume of tea plant waste production in the country, and the high content of phenolic compounds, including tannins, in this plant and its effect on feed digestibility, the present study investigated the effect of using tea waste extract on feed digestibility using gas production and in vitro degradability methods.

\section{Materials and Methods}

Preparation of tea waste and tea waste extract

Green and black tea wastes were prepared from tea factories in Lahijan city located in Gilan province (Gilan- Iran). To prepare the extract, $50 \mathrm{~g}$ of the sample was ground in a $2 \mathrm{~mm}$ sieve and mixed with 500 $\mathrm{ml}$ of $70 \%$ ethanol solution $(475 \mathrm{ml}$ of $99.95 \%$ ethanol and $25 \mathrm{ml}$ of distilled water) in an erlenmeyer. The mixture was incubated at 25 ${ }^{\circ} \mathrm{C}$ for $48 \mathrm{~h}$ and then extracted by Whatman filter No. 1. Ethanol was removed by a rotary evaporator (Alirezalu, Hesari, Eskandari, Valizadeh, \& Sirousazar, 2017). Total phenolic compounds, total extractable tannins, and condensed tannins were evaluated using the Makkar (2005) method.

Gas production, in vitro degradation, and in vitro digestibility

The rumen fluid required for the experimentswerepreparedusing two fistulated sheep fed a maintenance diet with $60 \%$ alfalfa and $40 \%$ concentrate feed. Rumen fluid was prepared from the sheep $2 \mathrm{~h}$ after morning feeding. It was passed through a filter cloth and then mixed with the artificial saliva buffer in a ratio of 1:2 proposed by McDougall (1948). The resulting mixture $(20 \mathrm{ml})$ was poured into sterile serum bottles containing $300 \mathrm{mg}$ of a basal diet (feed used in cattle farms with crude protein, insoluble fibers in a neutral detergent, insoluble fiber in an acidic detergent, ash, and crude fat each containing 15.3, 33.2, $24.3,6.6$, and $4.1 \%$ of DM, respectively. Feed ingredients were alfalfa, corn silage, straw, 
wheat bran, rice bran, sugar beet molasses, cottonseed, barley grain, corn grain, soybean, soymeal, sugar beet pulp, urea, di-calcium phosphate, calcium carbonate, magnesium oxide, salt, sodium bicarbonate, and vitamin and mineral supplements with $21.49,20.53$, $4.08,0.81,0.16,1.32,5.06,13.39,12.53,5.03$, $0.82,8.23,3.73,0.29,0.31,0.41,0.17,0.17$, 0.86 , and $0.57 \%$ of the diet DM, respectively. The bottles also contained extracts of black and green tea wastes $(5 \%$ of the basal diet DM). The serum vials were then anaerobicized by carbon dioxide injection and incubated at $39^{\circ} \mathrm{C}$ at $120 \mathrm{rpm}$.

Gas production from the fermentation was measured according to Fedorah \& Hrudey (1983). In this method, the produced gas is measured through the water displacement in graduated test tubes connected to tubes containing rumen fluid and feed sample. There were five replications for each experimental treatment. To correct the gas produced by the ruminal fluid origin, three tubes were filled with only $20 \mathrm{ml}$ of ruminal fluid and the buffer mixture (control) without adding the feed sample and placed in the incubator. At any time, the gas content produced by in this tube was subtracted from the total gas produced per hour to obtain the gas content produced by the experimental feed fermentation. The produced gas content was recorded at $2,4,6$, $8,12,24,48,72$, and $96 \mathrm{~h}$ after the incubation.

To determine the in vitro feed degradability, ruminal fluid, serum tubes, and experimental treatments were prepared exactly the same as the gas production procedure (Ayasan et al., 2020). The difference was that there were three replications for each treatment, tubes were immediately removed from the incubator after $2,4,8,12,24,48 m$ and
$72 \mathrm{~h}$ of incubation, and transferred to a freezer at $-21{ }^{\circ} \mathrm{C}$ to prevent further degradation. It should be noted that three blank tubes containing only $20 \mathrm{ml}$ of the mixture of ruminal fluid and buffer without the feed sample were incubated for each time series. These blank samples were used to correct the DMD. The tested tube samples were then thawed and centrifuged at $4000 \mathrm{rpm}$ for $10 \mathrm{~min}$. The supernatant was separated, the remaining part was washed with a special buffer (sodium hydrogen phosphate, potassium dihydrogen phosphate, sodium chloride, and distilled water), and re-centrifuged at $2500 \mathrm{rpm}$ for 10 min. This procedure was repeated twice and finally the residue was transferred to an oven at $105^{\circ} \mathrm{C}$ for $24 \mathrm{~h}$. The dry matter disappearance rate was measured based on the relationships reported by Paya, Taghizadeh, Janamohamadi and Moghadam. (2008).

In this study, four different digestion models which has already been described by Palangi, Macit and Bayat. (2020) and Palangi \& Besharati (2020) were compared to investigate the digestion process.

Mathematically, these models are specified as:

Model I) First-order kinetics model without lag phase: $\quad Y=a+b\left(1-e^{-c t}\right)$

Model II) First-order kinetics model with lag phase: $\quad Y=a+b\left(1-e^{-c(t+1)}\right)$

Model III) Gompertz model:

$$
Y=a+b\left(k-k^{e(c t)}\right) /(k-1)
$$

Model IV) Generalised Mitscherlich model:

$$
Y=a+b\left(1-e^{-c(t-n)-d(\sqrt{ } t-v)}\right)
$$

where, $Y=$ the quantity of either DM or CP, $a, b$, $\mathrm{c}, \mathrm{d}$ and $\mathrm{k}=$ parameters to be estimated, and $\mathrm{t}$ $=$ time. 
The gas production data were fitted to each model by nonlinear regression using the NLIN procedure of the SAS (SAS Institute, Inc., Cary, North Carolina, USA).

\section{Statistical calculations and analysis}

Metabolizable energy, specific lactation energy, and digestible organic matter (\%) of the samples were calculated using the equations presented by Menke et al. (1979) and Menke \& Steingass (1987). The contents short-chain fatty acids (SCFAs) were calculated based on the relationship proposed by Getachew, Makkar, \& Becker. (2002).

$\mathrm{ME}(\mathrm{MJ} / \mathrm{Kg} \mathrm{DM})=2.2+(0.136 \times \mathrm{GP})+(0.057 \times$ $\mathrm{CP})+\left(0.002859 \times \mathrm{CF}^{2}\right)$

$\mathrm{NEL}(\mathrm{MJ} / \mathrm{Kg} \mathrm{DM})=(0.101 \times \mathrm{GP})+(0.051 \times \mathrm{CP})$ $+(0.11 \times \mathrm{CF})$

OMD $(\% \mathrm{DM})=14.88+(0.8893 \times \mathrm{GP})+(0.448 \times$ $\mathrm{CP})+(0.651 \times$ ash $)$

SCFA $(\mathrm{m} \mathrm{mol} / 200 \mathrm{mg} \mathrm{DM})=(0.02222 \times \mathrm{GP})-$ 0.00425
Finally, the obtained data were analyzed by SAS (2018) software with the general linear model (GLM) procedure and in a completely randomized design with a statistical model of: $Y_{i j}=\mu+T_{i}+e_{i j}$ in which $Y_{i j}=$ the value of each observation, $\mu=$ total average, $T_{i}=$ the treatment effect, and $e_{i j}=$ test error.

\section{Results and Discussion}

Chemical and phenolic compounds of tea waste

According to the results, phenolic compounds in green and black tea wastes were significantly different from each other (Table 1). Total phenolic compounds, extractable tannins, and condensed tannins in green tea wastes were significantly higher than those in black tea wastes $(p<0.05)$.

\section{Table 1}

Phenolic compounds in green and black tea wastes (g/Kg DM)

\begin{tabular}{cccc|}
\hline Treatments & Total phenols & Total tannins & Condensed tannins \\
\hline Green tea waste & $20.3^{\mathrm{a}}$ & $14.8^{\mathrm{a}}$ & $5.9^{\mathrm{a}}$ \\
\hline Black tea waste & $18.7^{\mathrm{b}}$ & $12.7^{\mathrm{b}}$ & $5.0^{\mathrm{b}}$ \\
SEM & 0.034 & 0.368 & 0.062 \\
P-values & $<0.0001$ & 0.016 & $<0.0001$
\end{tabular}

SEM: Standard Error of the Mean 
This difference can be due to the breakdown of these compounds in black tea wastes during tea oxidation fermentation from green tea leaves in tea factories. This tea preparation process is performed to improve the tea quality and appearance, such as tea color and taste, which was similarly reported by other researchers (Muthumani \& Kumar, 2007; Ramdani, Chaudhry, \& Seal, 2013). Furthermore, Ayaşan (2020) and Palangi \& Macit (2021) stated that the percentage of plant DM depends on many factors such as species, growth stages of different parts of the plant, soil moisture and rainfall. The chemical composition of forage plants under natural conditions is influenced by factors such as topographic features, climatic conditions, harvest time and folds. The tea wastes used in the current study were by-product, which is created due to the processing of tea plant for human drinking. Therefore, their composition varies depending on the composition of original plant material, method of processing, and type of components extracted or removed, such as other agriculture by-products (Paya, Taghizadeh, Lashkari, \& Shirmohammadi, 2012). However, the total phenols composition of green tea (20.3 $\mathrm{g} / \mathrm{kg} \mathrm{DM})$ of this study was lower than those from a study by Khokhar \& Magnusdottir (2002), whereas the total phenols in black tea measured in this study (18.7 $\mathrm{g} / \mathrm{kg}$ DM) were also lower than in the study by Khokhar \& Magnusdottir (2002). These chemical differences could be expected because they refer to spent tea leaves after boiling in water as tea waste, but factory waste is used as a tea by-product in this study.

\section{Gas production}

The effects of adding black and green tea waste extracts on dietary gas production are shown in Table 2. According to the results, the addition of green and black tea waste extract significantly reduced gas production in all hours of incubation except for $2 \mathrm{~h}$ of incubation ( $p<0.05$ ). As mentioned above, the addition of green and black tea extracts significantly reduced the dietary gas production. After $96 \mathrm{~h}$ of incubation, the lowest and the highest gas production rates (250.1 and $279.3 \mathrm{ml} / \mathrm{g}$ of DM) belonged to treatments containing green tea extract and the control (without extract addition), respectively.

The estimated gas production characteristics are reported in Table 3, in which models 1, 2, 3, and 4 are the First-order kinetics model without lag phase, First-order kinetics model with lag phase, Gompertz model and generalised Mitscherlich model, respectively.

The effects of adding green and black tea waste extract on the estimated parameters of the feed nutritional value by gas production and chemical compounds, including metabolizable energy, specific lactation energy, digestible organic matter, and SCFAs are reported in Table 4. 
Table 2

In vitro gas production of feed sample incubated in buffered rumen fluid ( $\mathrm{ml} / \mathrm{g} \mathrm{DM}$ )

\begin{tabular}{|cccccc}
\hline \multirow{2}{*}{ Incubation time $(\mathrm{h})$} & \multicolumn{3}{c}{ Test feeds } & SEM & P-values \\
\cline { 2 - 4 } & GTW & BTW & Control & & 0.001 \\
\hline 2 & $45.0^{\mathrm{a}}$ & $41.8^{\mathrm{b}}$ & $46.3^{\mathrm{a}}$ & 0.68 & 0.0002 \\
\hline 6 & $71.5^{\mathrm{b}}$ & $69.6^{\mathrm{b}}$ & $78.6^{\mathrm{a}}$ & 1.08 & 0.001 \\
\hline 8 & $93.8^{\mathrm{b}}$ & $94.7^{\mathrm{b}}$ & $105.2^{\mathrm{a}}$ & 1.58 & 0.001 \\
\hline 12 & $123.3^{\mathrm{b}}$ & $122.0^{\mathrm{b}}$ & $133.9^{\mathrm{a}}$ & 1.91 & 0.002 \\
\hline 24 & $151.5^{\mathrm{b}}$ & $146.5^{\mathrm{b}}$ & $161.7^{\mathrm{a}}$ & 2.37 & 0.0005 \\
\hline 48 & $184.1^{\mathrm{b}}$ & $181.5^{\mathrm{b}}$ & $200.9^{\mathrm{a}}$ & 2.70 & 0.0001 \\
\hline 72 & $218.8^{\mathrm{b}}$ & $218.8^{\mathrm{b}}$ & $240.6^{\mathrm{a}}$ & 2.63 & 0.0001 \\
\hline 96 & $240.3^{\mathrm{b}}$ & $243.2^{\mathrm{b}}$ & $267.6^{\mathrm{a}}$ & 2.48 & 0.0001 \\
\hline
\end{tabular}

a,b Means within a column with different subscripts differ $(P<0.05)$.

GTW = diet with green tea waste extract; BTW = diet with black tea waste extract; Control = diet without any additives.

Table 3

\section{Estimated gas production characteristics}

\begin{tabular}{ccccccccccc} 
Model & $\mathrm{a}$ & $\mathrm{b}$ & $\mathrm{c}$ & $\mathrm{L}$ & $\mathrm{d}$ & $\mathrm{k}$ & $\mathrm{SSM}$ & $\mathrm{CSST}$ & $\mathrm{R}$-square & SEM \\
\hline GTW & & & & & & & & & & \\
\hline 1 & 23.7 & 216 & 0.066 & & & & 222090 & 226655 & 0.97 & 108.7 \\
\hline 2 & 36.6 & 203 & 0.066 & 0.92 & & & 222090 & 226655 & 0.97 & 108.7 \\
3 & 14.5 & 231 & 0.029 & & & 10.7 & 223451 & 226655 & 0.98 & 78.1 \\
\hline 4 & 45.0 & 236 & -0.009 & 0.58 & 0.34 & & 224571 & 226655 & 0.99 & 52.0 \\
\hline BTW & & & & & & & & & & \\
\hline 1 & 24.7 & 217 & 0.061 & & & & 230614 & 234827 & 0.98 & 100.3 \\
\hline 2 & 36.2 & 206 & 0.061 & 0.87 & & & 230614 & 234827 & 0.98 & 100.3 \\
3 & 15.3 & 233 & 0.028 & & & 9.6 & 232089 & 234827 & 0.98 & 66.7 \\
\hline 4 & 41.8 & 252 & -0.007 & 2.35 & 0.30 & & 233514 & 234827 & 0.99 & 32.8 \\
\hline Control & & & & & & & & & & \\
\hline 1 & 28.4 & 239 & 0.061 & & & & 278850 & 283424 & 0.98 & 108.9 \\
\hline 2 & 55.5 & 212 & 0.061 & 1.95 & & & 278850 & 283424 & 0.98 & 108.9 \\
\hline 3 & 18.0 & 256 & 0.028 & & & 9.7 & 280681 & 283424 & 0.99 & 66.8 \\
\hline 4 & 46.3 & 280 & -0.007 & 2.26 & 0.29 & & 282491 & 283424 & 0.99 & 23.3 \\
\hline
\end{tabular}

GTW = diet with green tea waste extract; BTW = diet with black tea waste extract; Control = diet without any additives; SSM: Sum of Square-Model; CSST: Corrected Sum of Squre-Total; SEM: Standard Error of the Mean

Model 1: First-order kinetics model without lag phase, 2: First-order kinetics model with lag phase, 3: Gompertz model and 4: generalised Mitscherlich model. 
Table 4

Estimated SCFA, ME and OMD by chemical composition and in vitro gas production results

\begin{tabular}{|c|c|c|c|c|c|}
\hline \multirow{2}{*}{ Incubation time (h) } & \multicolumn{3}{|c|}{ Test feeds } & \multirow{2}{*}{ SEM } & \multirow{2}{*}{ P-values } \\
\hline & GTW & BTW & Control & & \\
\hline ME (MJ.kg-1 DM) & $8.12^{\mathrm{b}}$ & $8.05^{b}$ & $8.58^{a}$ & 0.07 & 0.0005 \\
\hline NEI (MJ.kg-1 DM) & $4.95^{\mathrm{b}}$ & $5.29^{b}$ & $5.29^{a}$ & 0.05 & 0.0005 \\
\hline OMD (\%) & $60.08^{c}$ & $62.88^{b}$ & $69.58^{a}$ & 0.64 & 0.0001 \\
\hline SCFA (mmol. $\left.200 \mathrm{mg}^{-1} \mathrm{DM}\right)$ & $0.81^{b}$ & $0.80^{\mathrm{b}}$ & $0.88^{a}$ & 0.008 & 0.0005 \\
\hline
\end{tabular}

a, b, c Means within a column with different subscripts differ $(P<0.05)$.

GTW = diet with green tea waste extract; BTW = diet with black tea waste extract; Control = diet without any additives ME: Metabolizable Energy, NEl: Net Energy for lactation, OMD: Organic Matter Digestibility, SCFA: Short Chain Fatty Acid.

The no effect of adding the extract in the first $2 \mathrm{~h}$ of incubation can be due to no effect of phenolic compounds on the bacterial population in the early hours. Numerical differences in the effects of adding green and black tea extracts can also be caused by differences in the contents of phenolic compounds and the high levels of these compounds in green tea extract led to a greater effect on the reduction of gas production.

According to Menke \& Steingass (1987), the produced gas is affected only by the chemical composition and physical properties of feed. However, according to the results of the present study, the constant ingredients of the tested feed, and the reduction of gas production by the addition of black and green tea waste extracts, this reduction can could have resulted from the effect of phenolic compounds on the microbial population of ruminal fluid. In this regard, Razmaza, Torbatinejad, Seifdavati, \& Zerehdaran. (2016) investigated the effect of phenolic compounds on gas production and reported that these compounds reduced gas production by changing the population of ruminal microorganisms, including protozoa population. The same researchers examined the effect of pomegranate peel in three different cultivars that contain high amounts of phenolic compounds and tannins. These compounds reduced gas production and changed the gas production kinetics due to their inhibitory activity against a number of microorganisms involved in methane production and protozoa. Adding tannins at different increasing concentrations $(50,101$, and $151 \mathrm{~g} / \mathrm{kg}$ of DM) to diets of goats reduced the number of protozoa in the rumen (Animut et al., 2008). In line with the present study, Bodas et al. (2012) reported a decrease in the ruminal fiber degradability and consequently decreased gas production by the addition of tannins.

The gas production in all treatments had an increasing trend from the initial hours of incubation to $96 \mathrm{~h}$. There was a steep gas production slope up to $24 \mathrm{~h}$ of incubation, which decreased from $48 \mathrm{~h}$. The basal diet had a significantly higher slope than the diet containing green and black tea waste extracts from the first hours to $96 \mathrm{~h}$. The decreased slope of increasing gas production rate in the final hours of incubation for all treatments can 
be due to the reduction of nutrients for the consumption of microorganisms.

Based on the comparison of the models with the criteria of coefficient of determination and variance of error, model 4 has the highest coefficient of determination and the lowest variance of error and is the best model to statistically explain the gas production data in different experimental treatments. For the first and second treatments, the model 4 is the best biological model. However, since negative degradability rates have been obtained for the treatments tested in this model and have no biological justification, model 3 is selected as the best fitted model to explain the data in these experimental treatments.

The results show that the addition of green and black tea waste extracts has significantly reduced the amounts of these parameters. The reductions in the mentioned parameters are explained by their estimations based on the diet chemical analysis and the gas production rate, and by the fact that the addition of green and black tea waste extracts reduced the gas production of the diets.

\section{Apparent degradability of dry matter in vitro}

Based on data of the disappearance of feed DM (Table 5), the basal diet had the highest DMD in all incubation hours. After $2 \mathrm{~h}$ of incubation, all the three treatments were not significantly different from each other, which corresponded to the results of gas production. After $4 \mathrm{~h}$ of incubation, the DMD of the basal diet was higher than the diets containing green and black tea waste extracts ( $<<0.05$ ). After $24 \mathrm{~h}$ of incubation, there significant differences were observed between all the three treatments. The diet containing green tea waste extract and the base diet contained the lowest (53.6\%) and the highest (59.9\%) $D M D$, respectively $(p<0.05)$. The different DMD values between the treatments containing green tea and black tea waste extracts are represented in Table 2. Based on the results, significant differences were found between the basal diet and the diet containing green and black tea extracts after 12,48 and $72 \mathrm{~h}$ of incubation, and the basal diet had the highest DMD $(p<0.05)$.

\section{Table 5}

Dry matter disappearance (\% DM)

\begin{tabular}{|c|c|c|c|c|c|}
\hline \multirow{2}{*}{ Incubation time (h) } & \multicolumn{3}{|c|}{ Test feeds } & \multirow{2}{*}{ SEM } & \multirow{2}{*}{ P-values } \\
\hline & GTW & BTW & Control & & \\
\hline 2 & 22.7 & 20.5 & 22.8 & 0.84 & 0.17 \\
\hline 4 & $28.4^{b}$ & $28.5^{b}$ & $30.9^{a}$ & 0.62 & 0.05 \\
\hline 8 & $41.7^{b}$ & $41.9^{\mathrm{a}}$ & $45.4^{a}$ & 1.43 & 0.021 \\
\hline 12 & $43.6^{b}$ & $43.5^{b}$ & $46.1^{\mathrm{a}}$ & 0.78 & 0.0007 \\
\hline 24 & $53.6^{c}$ & $55.6^{b}$ & $59.9^{a}$ & 0.24 & 0.0001 \\
\hline 48 & $63.7^{b}$ & $62.9^{b}$ & $71.1^{a}$ & 1.07 & 0.003 \\
\hline 72 & $63.6^{b}$ & $66.9^{b}$ & $78.8^{a}$ & 1.04 & 0.0001 \\
\hline
\end{tabular}

$\mathrm{a}, \mathrm{b}, \mathrm{c}$ Means within a column with different subscripts differ $(P<0.05)$.

GTW = diet with green tea waste extract; BTW = diet with black tea waste extract; Control = diet without any additives 
The degradability characteristics of the experimental treatments are reported in Table 6, where models $1,2,3$, and 4 are the First-order kinetics model without lag phase,
First-order kinetics model with lag phase, Gompertz model and generalised Mitscherlich model, respectively.

Table 6

Estimated DM disappearance characteristics

\begin{tabular}{|ccccccccccc}
\hline Model & $\mathrm{a}$ & $\mathrm{b}$ & $\mathrm{c}$ & $\mathrm{L}$ & $\mathrm{d}$ & $\mathrm{k}$ & $\mathrm{SSM}$ & $\mathrm{CSST}$ & $\mathrm{R}$-square & SEM \\
\hline GTW & & & & & & & & & & \\
\hline 1 & 11.7 & 49.7 & 0.11 & & & & 3629 & 3791 & 0.957 & 10.7 \\
\hline 2 & 11.0 & 50.4 & 0.11 & -0.12 & & & 3629 & 3791 & 0.957 & 10.7 \\
\hline 3 & 9.8 & 53.6 & 0.04 & & & 17.7 & 3645 & 3791 & 0.961 & 10.4 \\
\hline 4 & 7.4 & 58.0 & 0.01 & 0.56 & 0.38 & & 3635 & 3791 & 0.959 & 11.1 \\
\hline BTW & & & & & & & & & & \\
\hline 1 & 11.4 & 40.5 & 0.10 & & & & 3842 & 3928 & 0.978 & 5.7 \\
\hline 2 & 20.0 & 41.8 & 0.10 & 1.77 & & & 3842 & 3928 & 0.978 & 5.7 \\
\hline 3 & 9.1 & 54.5 & 0.04 & & & 10.5 & 3858 & 3928 & 0.982 & 5.0 \\
\hline 4 & -4.7 & 83.8 & -0.01 & 0.18 & 0.38 & & 3861 & 3928 & 0.982 & 4.8 \\
\hline Control & & & & & & & & & & \\
\hline 1 & 11.7 & 57.2 & 0.10 & & & & 4905 & 5020 & 0.977 & 7.6 \\
\hline 2 & 18.5 & 50.4 & 0.10 & 1.16 & & & 4905 & 5020 & 0.977 & 7.6 \\
\hline 3 & 9.2 & 61.9 & 0.04 & & & 12.9 & 4931 & 5020 & 0.982 & 6.3 \\
\hline 4 & 19.3 & 60.4 & -0.009 & 1.70 & 0.41 & & 4932 & 5020 & 0.982 & 6.2 \\
\hline
\end{tabular}

GTW = diet with green tea waste extract; BTW = diet with black tea waste extract; Control = diet without any additives Model 1: First-order kinetics model without lag phase, 2: First-order kinetics model with lag phase, 3: Gompertz model and 4: generalised Mitscherlich model

Insignificance in the $2 \mathrm{~h}$ of incubation, could be due to the inability of phenolic compounds to affect the microorganism population in the early hours. The differentDMD values between the treatments containing green tea and black tea waste extracts can be attributed to changes in the phenolic contents of these two extracts. The highest DMD value can be deduced that the addition of black and green tea waste extracts resulted in decreased apparent DMD in the diet.
In line with the results of the present study, increasing tannin-rich diets was reported to reduce the DMD (Tiemann et al., 2008), which was attributed to the interference of tannins in cell wall degradability by the inhibition of microbial enzymes. In another study (Bodas et al., 2012), the effects of various sources containing tannins were examined on the feed degradability. It was reported that tannins reduced fiber degradability in the rumen and generally the DMD in the rumen, 
which was reasoned to result from changes in the rumen microbial population.

Phenolic compounds seem to change the fermentation process and final products by affecting the microorganism population. Likewise, a study (Cieslak, Zmora, PersKamczyc, \& Szumacher-Strabel, 2012) on tannin-containing plants reported that tannins reduced methane production by affecting the rumen microorganism population. Besides, they reduced the production of hydrogen by reducing the feed degradability, and these two mechanisms led to a reduction in energy loss through methane. The same researchers reported a $24-30 \%$ reduction in methane production by ruminants consuming tannincontaining feeds. However, they reported that feeding these tannin sources had no negative effects on the DMD, which is inconsistent with our results. These discrepant results might be because these researchers reported the digestibility of the whole $\mathrm{GI}$, but the present study measured ruminal degradability. However, it can be argued that phenolic compounds can cause the passage of nutrients through the rumen, as reported elsewhere (Ramdani, Chaudhry, \& Seal, 2013).

Based on the comparison of the models with the criteria of coefficient of determination and error variance, Model 4 has the highest coefficient of determination and the lowest variance of error and is the best model to statistically explain the DMD data of different experimental treatments. However, since negative degradability rates have been obtained for the treatments tested in this model and have no biological justification, model 3 is selected as the best fitted model to explain the data in these experimental treatments.

Ruminal-intestinal disappearance by McNiven's method

Ruminal-intestinal disappearance in experimental treatments was determined by McNiven's method. The ruminal, intestinal, and total GI disappearance rates of dry matter in the tested treatments are presented in Table 7. However, these results will be acceptable when this processing has no negative effect on the disappearance of diet DM in the small intestine, which was also examined in this experiment.

The results of McNiven's method showed that treatments containing black and green tea extracts had the highest disappearance of ruminal DM and were significantly different from the control $(p<0.05)$. The post-ruminal disappearance rate of undigested DM in the rumen indicates that the addition of black and green tea waste extracts containing phenolic compounds led to a significant increase $(p<0.05)$ in the intestinal dry matter disappearance. The control treatment had the least intestinal disappearance of the dry matter. 
Table 7

Ruminal, post-ruminal and total tract nutrient disappearance of test feeds by McNiven (\%)

\begin{tabular}{|cccc|}
\hline & Ruminal & Post-ruminal & Total tract \\
\hline GTW & $27.1 \mathrm{a}$ & $28.9 \mathrm{~b}$ & 56.1 \\
\hline BTW & $25.3 \mathrm{~b}$ & $32.0 \mathrm{a}$ & 57.3 \\
\hline Control & $24.9 \mathrm{~b}$ & $31.8 \mathrm{a}$ & 56.8 \\
\hline SEM & 0.23 & 0.68 & 0.64 \\
\hline p-values & 0.001 & 0.032 & 0.431 \\
\hline
\end{tabular}

a, b, c Means within a column with different subscripts differ $(P<0.05)$.

GTW = diet with green tea waste extract; BTW = diet with black tea waste extract; Control = diet without any additives.

The results showed that DM disappearance rate in the whole GI tract was not significantly different for all treatments. This means that the addition of tea waste extract shifted the dry matter digestion site from the rumen to the intestine and compensated for the reduced ruminal disappearance in treatments containing tea waste extract. This trend was also observed in the CP disappearance rates of raw and processed safflower seeds.

Phenolic compounds, including tannins, which are present in the extracts of black and green tea wastes, are able to form hydrogen bonds, in particular with proteins, which are relatively stable in the $\mathrm{pH}$ range of $3.5-8$, thereby preventing their ruminal degradation and reducing nutrient degradability in the rumen (Vasta et al., 2019). However, these bonds are broken and the compounds become digestible as the $\mathrm{pH}$ drops below 3.5, which occurs when the feed reaches the abomasum. Similarly, the results of the present experiment show this phenomenon and the intestinal disappearance rateincreases during the abomasum simulation by the addition of hydrochloric acid. Besides, the digestion and disappearance rates remain unchanged throughout the GI (Tran-Tu, Bosma,
Verstegen, \& Schrama, 2019; Liu et al., 2020). In other words, adding black and green tea waste extracts containing tannins shifts the digestion site from the rumen to the intestine. In line with our findings, Arisya, Ridwan, Ridla, \& Jayanegara. (2019) identified a reduction in the ruminal nutrient disappearance due to the addition of tannin-containing extracts derived from licorice (Calliandra calothyrsus) and mountain dahlia (Clidemia hirta).

\section{Conclusions}

Given the high volume of tea waste production in the country, the use of this agricultural waste is of special importance. Considering the high content of phenolic compounds and tannins in these agricultural wastes and the results of this study, the addition of the extract obtained from black and green tea wastes reduced the gas production and ruminal degradability. On the other hand, the obtained results demonstrate that adding black and green tea waste extracts shifted the digestion site from the rumen to the intestine. Depending on nutritional strategies, it is sometimes important to escape nutrients from rumen and prevent ruminal breakdown 
of nutrients, thereby increasing the feed use efficiency, for which it is possible to use the extracts of black and green tea waste.

\section{Authors' contributions}

NSG, HP and AT developed the original hypotheses and designed the experiments, $\mathrm{HM}$ and YM conducted the statistical analyses, VP collaborated in interpreting the results and finalized the manuscript. Both authors have read and approved the finalized manuscript.

\section{Conflict of Interest Declaration}

The authors declare that they have no conflict of interest.

\section{Compliance with Ethical Standards}

Ethical protocol was approved by the experimental animal ethics committee of University of Tabriz, Tabriz, Iran.

\section{References}

Adejoro, F. A., Hassen, A., \& Akanmu, A. M. (2019). Effect of lipid-encapsulated acacia tannin extract on feed intake, nutrient digestibility and methane emission in sheep. Animals, 9(11), 863. doi: 10.3390/ ani 9110863

Alirezalu, K., Hesari, J., Eskandari, M. H., Valizadeh, H., \& Sirousazar, M. (2017). Effect of green tea, stinging nettle and olive leaves extracts on the quality and shelf life stability of frankfurter type sausage. Journal of Food Processing and Preservation, 41(5), e13100. doi: 10.1111/jfpp.13100
Animut, G., Puchala, R., Goetsch, A. L., Patra, A. K., Sahlu, T., Varel, V. H., \& Wells, J. (2008). Methane emission by goats consuming diets with different levels of condensed tannins from lespedeza. Animal Feed Science and Technology, 144(3-4), 212-227. doi: 10.1016/j.anife edsci.2007.10.014

Arisya, W., Ridwan, R., Ridla, M., \& Jayanegara, A. (2019). Tannin treatment for protecting feed protein degradation in the rumen in vitro. In Journal of Physics: Conference Series, 1360(1), 012022. doi: 10.1088/ 1742-6596/1360/1/012022

Ayaşan, T. (2020). Determination of nutritional value of some quinoa varieties. Turkish Journal of Veterinaryand Animal Sciences, 44(4), 950-954. doi: 10.3906/vet-2003-53

Ayasan, T., Sucu, E., Ülger, I., Hizli, H., Çubukcu, P., \& Özcan, B. D. (2020). Determination of in vitro rumen digestibility and potential feed value of tiger nut varieties. South African Journal of Animal Science, 50(5), 738-744. doi: 10.4314/sajas.v50i5.12

Besharati, M., Palangi, V., Moaddab, M., Nemati, Z., Pliego, A. B., \& Salem, A. Z. (2020). Influence of Cinnamon Essential Oil and Monensin on Ruminal Biogas Kinetics of Waste Pomegranate Seeds as a Biofriendly Agriculture Environment. Waste and Biomass Valorization, (in press), 1-10. doi: 10.1007/s12649-020-01167-2

Bodas, R., Prieto, N., García-González, R., Andrés, S., Giráldez, F. J., \& López, S. (2012). Manipulation of rumen fermentation and methane production with plant secondary metabolites. Animal Feed Science and Technology, 176(1-4), 78-93. doi: 10.10 16/j.anifeedsci.2012.07.010 
Cieslak, A., Zmora, P., Pers-Kamczyc, E., \& Szumacher-Strabel, M. (2012). Effects of tannins source (Vaccinium vitis idaea L.) on rumen microbial fermentation in vivo. Animal Feed Science and Technology, 176(1-4), 102-106. doi: 10.1016/j.anifeed sci.2012.07.012

Cimrin, T., Tunca, R. I., Avsaroglu, M. D., Ayasan, T., \& Küçükersan, S. (2020). Effects of an antibiotic and two phytogenic substances (cinnamaldehyde and 1, 8-cineole) on yolk fatty acid profile and storage period-associated egg lipid peroxidation level. Revista Brasileira de Zootecnia, 49, e20190270. doi: 10.37496/ rbz4920190270

Costa, E. D. S., Ribiero, C. V. D. M., Silva, T. M., Ribeiro, R. D. X., Vieira, J. F., Lima, A. D. O., \& Oliveira, R. L. (2021). Intake, nutrient digestibility, nitrogen balance, serum metabolites and growth performance of lambs supplemented with Acacia mearnsii condensed tannin extract. Animal Feed Science and Technology, 272, 114744. doi: 10.1016/j.anifeedsci.2020.114744

Derix, J. (2017). The effect of high tannin concentrations in feed on protein digestion: grazers versus intermediate browsers. Ghent: Ghent University.

Fedorah, P. M., \& Hrudey, S. E. (1983). A simple apparatus for measuring gas production by methanogenic cultures in serum bottles. Environmental Technology, 4(10), 425432. doi: 10.1080/0959333830938422 8

Georganas, A., Giamouri, E., Pappas, A. C., Papadomichelakis, G., Galliou, F., Manios, T., \& Zervas, G. (2020). Bioactive compounds in food waste: a review on the transformation of food waste to animal feed. Foods, 9(3), 291. doi: 10.3390/ foods 9030291

Getachew, G., Makkar, H.P.S., \&Becker, K. (2002). Tropical browses: contents of phenolic compounds, in vitro gas production and stoichiometric relationship between short chain fatty acid and in vitro gas production. The Journal of Agricultural Science, 139(3), 341-352. doi: 10.1017/S 0021859602002393

Kelln, B., Penner, G. B., Acharya, S. N., McAllister, T. A., \& Lardner, H. A. (2020). Impact of condensed tannin containing legumes on ruminal fermentation, nutrition and performance in ruminants: a review. Canadian Journal of Animal Science, (in press). doi: 10.1139/CJAS-2020-0096

Khokhar, S., \& Magnusdottir, S. G. M. (2002). Total phenol, catechin, and caffeine contents of teas commonly consumed in the United Kingdom. Journal of Agricultural and Food Chemistry, 50(3), 565-570. doi: 10.1021/ jf010153।

Koenig, K. M., \& Beauchemin, K. A. (2018). Effect of feeding condensed tannins in high protein finishing diets containing corn distillers grains on ruminal fermentation, nutrient digestibility, and route of nitrogen excretion in beef cattle. Journal of Animal Science, 96(10), 4398-4413. doi: 10.1093/ jas/sky27 3

Kondo, M., Hirano, Y., Ikai, N., Kita, K., Jayanegara, A., \& Yokota, H. O. (2014). Assessment of anti-nutritive activity of tannins in tea by-products based on in vitro rumen fermentation. Asian-Australasian Journal of Animal Sciences, 27(11), 1571-1576. doi: 10.5713/ajas.2014.14204 
Liu, Z. Y., Hu, Y. Y., Zhao, M. T., Xie, H. K., Hu, X. P., Ma, X. C., \& Zhou, D. Y. (2020). Formation and disappearance of aldehydes during simulated gastrointestinal digestion of fried clams. Food \& Function, 11(4), 34833492. doi: 10.1039/C9F003021B

Makkar, H. P. (2005). Use of nuclear and related techniques to develop simple tannin assays for predicting and improving the safety and efficiency of feeding ruminants on tanniniferous tree foliage: achievements, result implications, and future research. Animal Feed Science and Technology, 122(1-2), 3-12. doi: 10.1016/j. anifeedsci.2005.04.001

McDougall, E. I. (1948). Studies on ruminant saliva. 1. The composition and output of sheep's saliva. Biochemical Journal, 43(1), 99-109. doi: 10.1042/bj0430099

Menke, K. H., Raab, L., Salewski, A., Steingass, H., Fritz, D., \& Schneider, W. (1979). The estimation of the digestibility and metabolizable energy content of ruminant feedingstuffs from the gas production when they are incubated with rumen liquor in vitro. The Journal of Agricultural Science, 93(1), 217-222. doi: 10.1017/ S0021859600086305

Menke, K. H., \& Steingass, H. (1987). Estimation of the energetic feed value obtained from chemical analysis and in vitro gas production using rumen fluid. Animal Research and Development, 28, 7-12. Recoveredfromhttps://www.scienceopen. com/document?vid=e1859372-e696424a-85fb-d305b0b594 bc

Min, B. R., Solaiman, S., Waldrip, H. M., Parker, D., Todd, R. W., \& Brauer, D. (2020). Dietary mitigation of enteric methane emissions from ruminants: a review of plant tannins mitigation options. Animal Nutrition, 6(3), 231-246. doi: 10.1016/j. aninu.2020.05.002

Mohamaden, W. I., Hegab, I. M., \& Shang-li, S. (2020). In situ ruminal degradation kinetics and blood metabolites as affected by feeding different sources of tannin and flavonoids to small-tailed Han rams. Livestock Science, 239, 104029. doi: 10. 1016/j.livsci.2020.104029

Muthumani, T., \& Kumar, R. S. (2007). Influence of fermentation time on the development of compounds responsible for quality in black tea. Food Chemistry, 101(1), 98-102. doi: 10.1016/j.foodchem.2006.01. 008

Palangi, V., \& Besharati, M. (2020). Validation of in situ disappearance curves utilizing mathematical models for incubating fish meal and cottonseed meal. Semina: Ciências Agrárias, 41(6, Supl. 2), 33913396. doi: 10.5433/1679-0359.2020v41 n6Supl2p3391

Palangi, V., \& Macit, M. (2021). Indictable mitigation of methane emission using some organic acids as additives towards a cleaner ecosystem. Waste and Biomass Valorization, (in press), 1-10. doi: 10.1007/ s12649-021-01347-8

Palangi, V., Macit, M., \& Bayat, A. R. (2020). Mathematical models describing disappearance of lucerne hay in the rumen using the nylon bag technique. South African Journal of Animal Science, 50(5), 719-725. doi: 10.4314/sajas.v50i5.9

Patra,A.K., \&Aschenbach, J.R. (2018).Ureasesin the gastrointestinal tracts of ruminant and monogastric animals and their implication in urea-N/ammonia metabolism: a review. Journal of Advanced Research, 13, 39-50. doi: 10.1016/j.jare.2018.02.005 
Patra, A. K., \& Saxena, J. (2011). Exploitation of dietary tannins to improve rumen metabolism and ruminant nutrition. Journal of the Science of Food and Agriculture, 91(1), 24-37. doi: 10.1002/ jsfa.4152

Paya, H., Taghizadeh, A., Janamohamadi, H., \& Moghadam, G. A. (2008). Ruminal dry matter and crude protein degradability of some tropical (Iranian) feeds used in ruminant diets estimated using the in situ and in vitro techniques. Research Journal of Biological Sciences, 3(7), 720-725. Recovered from https:// medwelljournals. com/abstract/?doi=rjbsci.2008.720.725

Paya, H., Taghizadeh, A., Lashkari, H., \& Shirmohammadi, S. (2012). Evaluation of rumen fermentation kinetics of some by-products using in situ and in vitro gas production technique. Slovak Journal of Animal Science, 45(4), 127-133. Recovered from https://sjas.ojs.sk/sjas/ article/view/291

Piluzza, G., Sulas, L., \& Bullitta, S. (2014). Tannins in forage plants and their role in animal husbandry and environmental sustainability: a review. Grass and Forage Science, 69(1), 32-48. doi: 10.1111/gfs. 12053

Ramdani, D., Chaudhry, A. S., \& Seal, C. J. (2013). Chemical composition, plant secondary metabolites, and minerals of green and black teas and the effect of different teato-water ratios during their extraction on the composition of their spent leaves as potential additives for ruminants. Journal of Agricultural and Food Chemistry, 61(20), 4961-4967. doi: 10.1021/jf4002439

Razmaza, V., Torbatinejad, N. M., Seifdavati, J., \& Zerehdaran, S. (2016). Effect of different varieties of pomegranate peels (Torsh Jangali Gorgan, malas Behshahr and Shirin kolbad) on dry matter digestibility, number of protozoa and methane production in vitro. Journal of Ruminant Research, 4(2), 111-132. doi: 10.22069/EJRR.2016.3230

Salami, S. A., Luciano, G., O'Grady, M. N., Biondi, L., Newbold, C. J., Kerry, J. P., \& Priolo, A. (2019). Sustainability of feeding plant byproducts: A review of the implications for ruminant meat production. Animal Feed Science and Technology, 251, 37-55. doi: 10.1016/j.anifeedsci.2019.02.006

Sallam, S. M., Attia, M. F., El-Din, A. N. N., ElZarkouny, S. Z., Saber, A. M., El-Zaiat, H. M., \& Zeitoun, M. M. (2019). Involvement of Quebrachotanninsin dietalters productive and reproductive efficiency of postpartum buffalo cows. Animal Nutrition, 5(1), 80-86. doi: 10.1016/j.aninu.2018.08.003

Samal, L., Chaudhary, L. C., Agarwal, N., \& Kamra, D. N. (2018). Impact of phytogenic feed additives on growth performance, nutrient digestion and methanogenesis in growing buffaloes. Animal Production Science, 58(6), 1056-1063. doi: 10.1071/ AN15610

Shakeri, P., Riasi, A., \& Madahian, A. (2018). Use of pistachio by-product extracts by different solvents to reduce ruminal degradability of canola meal protein. Research on Animal Production (Scientific and Research), 9(20), 61-69. doi: 10.29252/ rap.9.20.61

Smeriglio, A., Barreca, D., Bellocco, E., \& Trombetta, D. (2017). Proanthocyanidins and hydrolysable tannins: occurrence, dietary intake and pharmacological effects. British Journal of Pharmacology, 174(11), 1244-1262. doi: 10.1111/bph.13630 
SAS (2018). Institute Inc. SAS/CONNECT ${ }^{\circledR} 9.4$ User's Guide. Fourth Edition. Cary. NC: SAS Institute Inc.

Tiemann, T. T., Lascano, C. E., Wettstein, H. R., Mayer, A. C., Kreuzer, M., \& Hess, H. D. (2008). Effect of the tropical tannin-rich shrub legumes Calliandra calothyrsus and Flemingia macrophylla on methane emission and nitrogen and energy balance in growing lambs. Animal, 2(5), 790-799. doi: 10.1017/S1751731108001791

Tran-Tu, L. C., Bosma, R. H., Verstegen, M. W. A., \& Schrama, J. W. (2019). Effect of dietary viscosity on digesta characteristics and progression of digestion in different segments of the gastrointestinal tract of striped catfish (Pangasionodon hypophthalmus). Aquaculture, 504, 114120. doi: $10.1016 / \mathrm{j}$.aquaculture.2019.01. 047
Vasta, V., Daghio, M., Cappucci, A., Buccioni, A., Serra, A., Viti, C., \& Mele, M. (2019). Invited review: Plant polyphenols and rumen microbiota responsible for fatty acid biohydrogenation, fiber digestion, and methane emission: experimental evidence and methodological approaches. Journal of Dairy Science, 102(5), 3781-3804. doi: 10.3168/jds.2018-14985

Zhang, J., Xu, X., Cao, Z., Wang, Y., Yang, H., Azarfar, A., \& Li, S. (2019). Effect of different tannin sources on nutrient intake, digestibility, performance, nitrogen utilization, and blood parameters in dairy cows. Animals, 9(8), 507. doi: 10.3390/ani 9080507 
